\title{
288. 従来の平行グリッドと低格子比クロスグリッドの特性評価
}

\author{
济生会横浜市南部病院 中央放射線部 ○蕗 利彦, 木村英正, 传野常晴, 林 幸一 \\ 岩崎千代子，鈴木靖範, 綿費 移, 板橋慎二, 千葉 茂, \\ 鈴木安広, 山田正美, 泉 和弥, 有賀康城, 小宮秀朗, \\ 山城哲也，小沢文親。 \\ 竹内研究所 \\ 大内義雄, 崖山初昭。
}

【目的】X線撮影に於いて良いX線写真を撮る手法にGridの使用頻度は高い。一般にGridと云えば 平行Gridを指し。多くの施設で使用されている。物理評価における Singl Grid の Bucky factor は Cross grid より良いが、Contrast 改善度及び選択度では Cros grid が良い。Cross g rid の bucky factor の改善には低格子比 Grid が考えられるけれど画像の低下を生じないことが必要で ある。今回、我々はこの必要且つ十分な条件を追及するために低格子比の Cross grid 4 種類試 作し。8:1,10:1(Sing1 grid)と合わせて物理特性及び臨床評価を検討したので報告する。

【方法】测定方法は JIS-4910 に準じた。

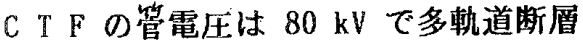
(LGU 東芝)を使用した。X線散乱線量分 布を求めるために照射野 $(30 \times 30)$ でフ ルム濃度崭囲 $(1.0 \pm 0.02)$ の湄度分布を 求め、線量分布はTLD-170L素子を图 1 の 様な配置にして照射し、3 回試行の平均 值から散乱線線量除去分布を求めた。 【結果】表 1，Grid の物理的評価は $60 \mathrm{kV}, 80 \mathrm{kV}, 120 \mathrm{kV}$ に於ける 1 , 全 X線 透過率 (Tt) 2,散乱 X 線透過率 (Ts) 3 , 一 次 X線透過率 (Tp) 4, 露出倍数 $(\mathrm{B}=1 / \mathrm{Tt})$

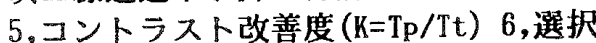
度 $(\Sigma=\mathrm{Tp} / \mathrm{Tt})$ の様になった。図1,は Singl grid と Cross grid の透過線量 分布である。図2，は低格子比 Cross g'rid とSingl grid を比較したCTF である。臨床的には良い評伍をえた。 【考祭】X線透過線量分布からも分かる 通り Singl Grid は体軸方向に対する散 乱線除去は低く、その点では散乱線を均 等に除去するCross gridの方が良い。 露出倍数はRatioを $1 / 2$, Lead contentを 1/2にしたとで十分改善された。然し、 コントラスト改善度についての物理評価 は低いが、CTFでは近差かやや上位にある。 いずれに主体性を置くか問題を残す所で ある。何れにしても我々は臨床評価を重 視する点にあるから良好と云う評価は今 後の励みになる。

【まとめ】今回の実験からCross gridは Ratioを低くしても十分 Singl grid の highi raiioに远敵することが分かった。 又、JIS 測定でコントラスト改善度を良く するポイントは鉛容積にあり、この值を変 えることで露出倍数, コントラスト改善度 は向上するものと思われる。
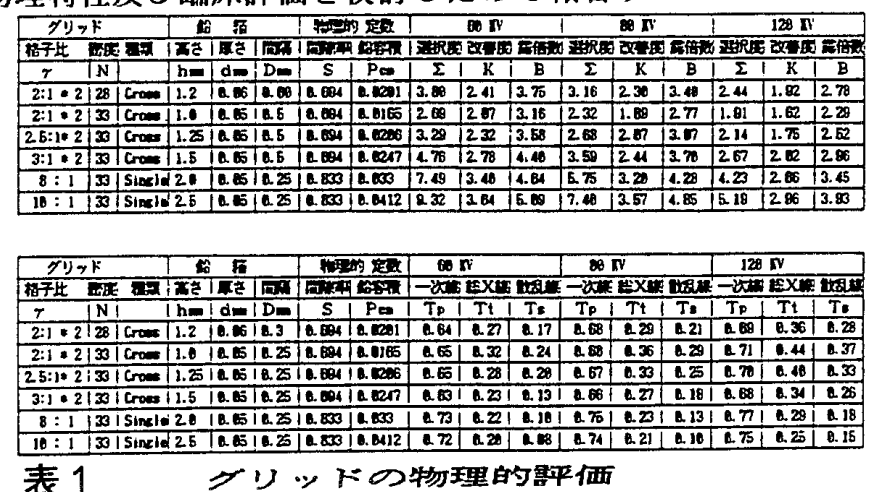

表 1

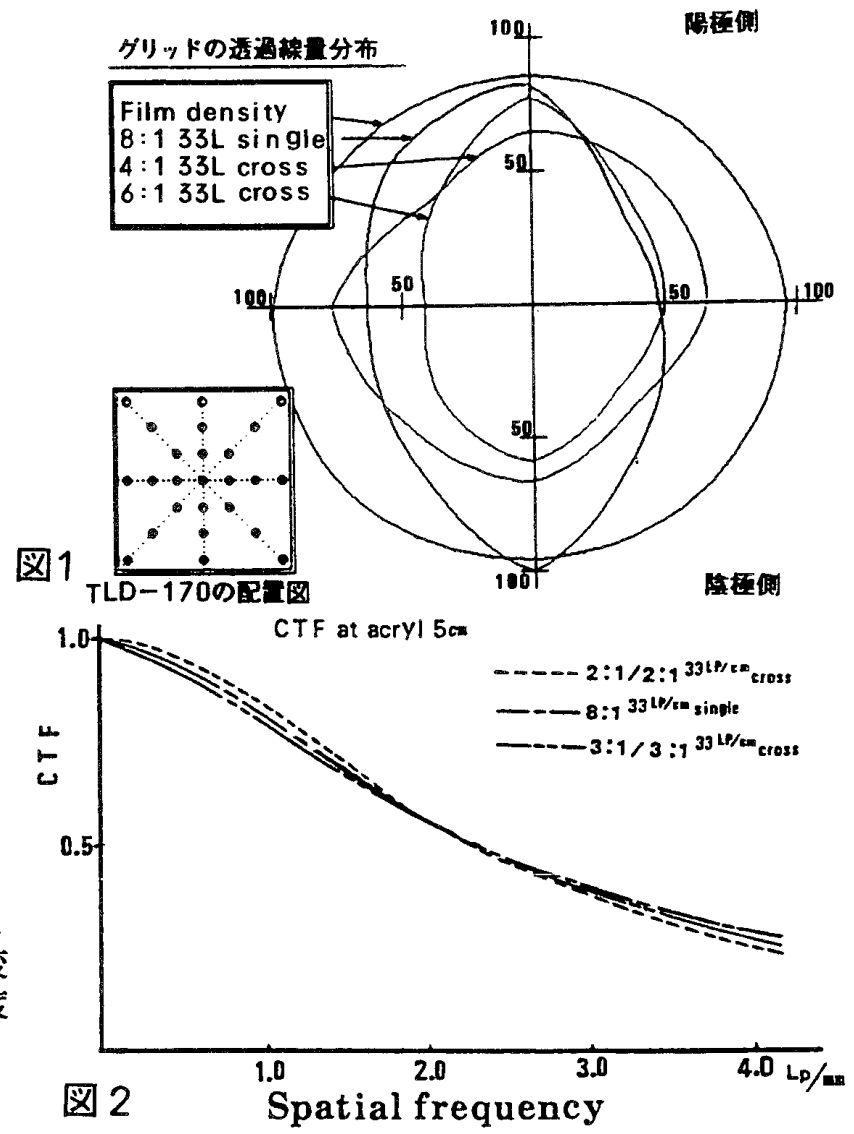

